\title{
DNA sequence information resolves taxonomic ambiguity of the common mud crab species (Genus Scylla) in Indian waters
}

\author{
C. P. Balasubramanian ${ }^{1}$, S. S. Cubelio ${ }^{2}$, D. L. Mohanlal ${ }^{1}$, A. G. Ponniah', Raj Kumar ${ }^{2}$, K. K. Bineesh², P. Ravichandran ${ }^{1}$, \\ A. Gopalakrishnan ${ }^{1}$, A. Mandal ${ }^{2} \dagger$, and J. K. Jena ${ }^{3}$ \\ ${ }^{1}$ Central Institute of Brackishwater Aquaculture, Chennai, Tamil Nadu, India, ${ }^{2}$ National Bureau of Fish Genetic Resources Cochin Unit, Kochi, Kerala, \\ India, and ${ }^{3}$ National Bureau of Fish Genetic Resources, Lucknow, Uttar Pradesh, India
}

\begin{abstract}
For several years, mud crabs of genus Scylla have been misidentified owing to their high morphological plasticity and the absence of distinct morphological diagnostic characters. The taxonomic confusion of genus Scylla de Haan is considered to be a primary constraint to the development of aquaculture. Although genus Scylla was revised using morphological and genetic characteristics, taxonomy of Scylla species occurring in India is still not clear. In this study, partial sequences of two mitochondrial genes, 16S rRNA and CO1 (Cytochrome C oxidase subunit I) in populations of Scylla spp. obtained from eleven locations along the Indian coast were used to differentiate and resolve taxonomical ambiguity of the mud crab species in India. The sequences were compared with previously published sequences of Scylla spp. Both trees generated based on 16S rRNA and CO1 indicated that all S. tranquebarica morphotypes obtained during this study and S. tranquebarica sequences submitted previously from Indian waters reciprocally monophyletic with reference sequence of $S$. serrata. Both sequence data and morphological characters revealed that the species S. serrata (Forskal) is the most abundant followed by S. olivacea. Further, the 16S rRNA and COI haplotypes of Indian S. tranquebarica obtained in the study significantly differed with the known S. tranquebarica by $6.7 \%$ and $10.6 \%$ respectively whereas it differed with known $S$. serrata by $0.0-0.7 \%$ only, a difference that was not statistically significant. From these studies it is clear that "S. tranquebarica" commonly reported from India should be S. serrata (Forskal).
\end{abstract}

\section{Keywords}

$16 \mathrm{~S}$ gene, Cytochrome oxidase 1 gene, mud crabs, phylogeny, Scylla, taxonomy

\section{History}

Received 9 December 2013

Revised 19 January 2014

Accepted 25 January 2014

Published online 24 March 2014

\section{Introduction}

Mud crabs of the genus Scylla, has been the focus of diversification of coastal aquaculture industry in India and several southeast Asian countries (Paterson \& Mann, 2011). They are one of the most widely exploited coastal fishery resources in this region (Jirapunpipat et al., 2009). Identification of Scylla species has been contentious because of the morphological plasticity, overlapping morphological and morphometric traits. Mud crabs were originally assigned into three species and one variety: S. oceanica, S. tranquebarica, S. serrata, S. serrata var. paramamosain (Estampador, 1949). However, Stephenson \& Campbell (1960) questioned this classification as they felt slight morphological changes and difference in color were of little importance to create new species. Thus, they tentatively fused all these forms and suggested one species, S. serrata.

\footnotetext{
*Present address: Central Marine Fisheries Research Institute, Kochi 682 018, Kerala, India

$\dagger$ Present address: Rajiv Gandhi Centre for Aquaculture, Sirkazhi 609 109, Tamil Nadu, India

Correspondence: C. P. Balasubramanian, Central Institute of Brackishwater Aquaculture, Chennai 600 028, Tamil Nadu, India. Tel: 0091 9444935541. E-mail: cpbalasubramanian@yahoo.com
}

Nevertheless, subsequent authors provided convincing arguments for the existence of two or three species of Scylla in several regions of its distribution (Joel \& Raj, 1983; Kathirval \& Srinivasagam, 1992). Later, Keenan et al. (1998) revised the taxonomy of genus Scylla "less controversially" based on the collections made all over the Indo-Pacific region and they recognized four species of Scylla: S. serrata (former S. oceanica), S. tranquebarica, S. olivacea (former $S$. serrata) and $S$ paramamosain (former $S$. serrata var. paramamosain). They used morphological, morphometric and molecular tool, and suggested three most useful morphometic ratios: inner carpus spine to outer carpus spine, frontal median spine height to frontal width and frontal width to internal carapace width. Nevertheless, they reported that no single ratio will discriminate the four species. Although classification of Keenan et al. (1998) is widely accepted, some authors raised doubts about the validity of this revised classification (Ronquillo et al., 1999). Although Keenan et al. (1998) analyzed specimens from almost all over the distributional range of this group, the common species supporting aquaculture and fisheries varies from region to region.

From Indian waters, originally two color morphs (dark green and greenish brown) of Scylla were recognized (Joel \& Raj, 1983; Kathirvel, 1981; Radhakrishnan \& Samuel, 1982). Kathirval \& Srinivasagam (1992), later, revised the taxonomy of mud crabs and reported two species of Scylla: S. tranquebarica and $S$. serrata for dark green and greenish brown morphs respectively. Scylla serrata is the most preferred species for coastal aquaculture 
in India (Kathirvel et al., 2004), however, it has been erroneously reported as $S$. tranquebarica in many scientific literature from India (Jithendran et al., 2010; Mohanty et al., 2006), partly due to the subtle diagnostic characteristics and overlapping morphometric ratios of $S$. tranquebarica and $S$. serrata (Jirapunpipat et al., 2008). Knowledge of Indian mud crab population remains inadequate, despite the importance of this species in both coastal aquaculture and artisanal fisheries of all the coastal states of India. Therefore, there is a clear need to identify the mud crab species in India using molecular tools as morphological diagnostic characteristics of mud crabs are rather weak or specific to life stages or sex. It is crucial to investigate what species is dominant in coastal aquaculture in India, as an incorrect name application can affect the success of aquaculture industry, and it can lead to the farming of a wrong species (Wowor \& $\mathrm{Ng}$, 2007), or utilizing the fund to develop a technology for the aquaculture of an economically or biologically unsuitable species. Mitochondrial markers have been widely used to accurately identify, resolve taxonomic ambiguity, forensic identification and describing new species across the tree of life (Hebert et al., 2003). In this paper we have used mitochondrial 16S rRNA and Cytochrome c oxidase subunit I (COI) nucleotide sequences to identify the mud crab species and to compare the present results in relation to those of other studies (Keenan et al., 1998).

\section{Materials and methods}

Animals were obtained from 11 different locations along the coast of India (Figure 1). Most specimens used for the study were from artisanal coastal fisheries, although few aquacultured samples were also used. Samples were caught by baited lift net or bottom set gill nets. More than 100 individuals were obtained and for molecular studies 30 representative samples from each location were used. In almost all cases live tissues were examined. For each specimens muscle tissues of the fifth pereopod was dissected and stored in $95 \%$ ethanol.

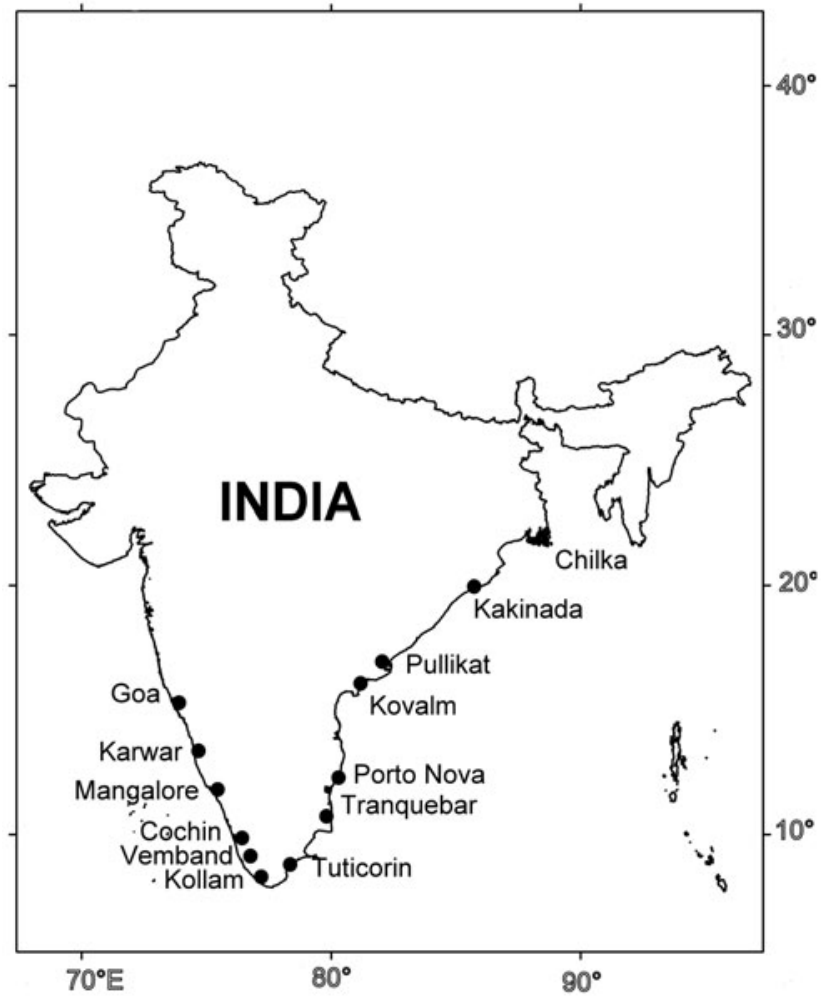

Figure 1. Map of India showing sampling sites of genus Scylla.

\section{Classification of specimens}

Before proceeding for genetic analysis, specimens were classified on the basis of taxonomically important characters: presence of polygonal marking on the chelipeds and other pereopods, shape and height of the frontal spines, shape of the interspaces of frontal spines, spines on the carpus of chelipeds and convexity of anterolateral spines (Keenan et al., 1998). Most specimens were assigned to two species: S. serrata and S. olivacea. However, few specimens ambiguous in morphology of $S$. tranquebarica (Keenan et al., 1998) were tentatively assigned as S. tranquebarica morphotypes.

\section{DNA extraction, PCR amplification and sequencing}

Genomic DNA was extracted from the alcohol preserved muscle tissues using phenol-chloroform extraction protocol of Kocher et al. (1989). Partial 16S rRNA gene was PCR-amplified using the primers 16Sar (5'CGCCTGTTATCAAAACAT3') and 16Sbr (5'GGTCTGAACTCAGATCACGT3') described by Iamai et al. (2004) and Somboonna et al. (2010). Polymerase chain reaction (PCR) used $10 \mathrm{ng}$ of template DNA, 0.25 unit of Taq Polymerase, $200 \mu \mathrm{M}$ of each of four deoxy nucleotide, $200 \mathrm{nM}$ of each of forward and reverse primers and $2.5 \mu \mathrm{L}$ of 1 X PCR buffer. The cycling profile was: 35 cycles of denaturation $\left(95^{\circ} \mathrm{C}\right.$ for $\left.30 \mathrm{~s}\right)$, annealing $\left(47^{\circ} \mathrm{C}\right.$ for $\left.40 \mathrm{~s}\right)$ and extension $\left(72^{\circ} \mathrm{C}\right.$ for $\left.1 \mathrm{~min}\right)$ with an initial denaturation step of $95^{\circ} \mathrm{C}$ for $5 \mathrm{~min}$ and final extension step at $72{ }^{\circ} \mathrm{C}$ for $10 \mathrm{~min}$. The partial sequence of mitochondrial cytochrome oxidase subunit 1 was gene was amplified and sequenced with primers CO1-f (5'TCCTGCAGGAGGAGGAG A $\left.3^{\prime}\right)$ and CO1-d(5'CTGGGTAGTCTGAATAACGT3') following similar procedure as for the $16 \mathrm{~S}$ rRNA gene.

PCR products were purified with gel purification kit (Real Biotech Corporation, Banqiao city Taiwan) and sequenced in ABI prism capillary sequencer following manufacture's instruction. The gene sequences of $16 \mathrm{~S}$ and CO1 of S. serrata, S. olivacea, S. tranquebarica and Portunus pelagicus were retrieved from GenBank (Table 2). Additionally, six 16S gene sequences of $S$. tranquebarica deposited in the Genbank from India were also retrieved (Table 2). These sequences were combined with the sequences obtained in the present study and aligned by using ClustalW (Thompson et al., 1994) in MEGA5. Pair-wise evolutionary distance among sequences was determined by the Kimura 2-Parameter methods (Kimura, 1980) using the software program MEGA5 (Tempe, AZ) (Tamura et al., 2011). The statistical significance of the pair wise inter species genetic distance measures between species was evaluated using Students' $t$-test. Neighbor-Joining (NJ) and Maximum Parsimony (MP) trees were constructed using MEGA5, and to verify the robustness of the internal nodes of NJ and MP trees, bootstrap analysis was carried out using 1000 pseudo replication (Felsenstein, 1993).

\section{Results}

Thirty new sequences (twenty $16 \mathrm{~S}$ and ten CO1) of mud crabs were obtained, and these sequences were aligned with publically available mud crab and out group sequences (Tables 1 and 2). No interons or indels were observed in the CO1 gene. After alignment, 16S fragment had 592 nucleotide sites and of which 107 sites were variable and 81 were parsimony informative. Of 549 nucleotide sites of CO1, 122 sites were variable and 85 sites were parsimony informative (Table 3). The AT content of both $16 \mathrm{~S}$ and $\mathrm{CO} 1$ were rich (16S: $68.8 \%$; CO1: 64.7\%)

To investigate the relationship of Indian species with other mud crab species, phylogenies were produced using our original data and published sequence data. Both neighbor joining and maximum parsimony trees are identical. Phylogenetic analysis of 
Table 1. Specimens of Scylla examined, Genbank accession numbers for genes sequenced and source of materials.

\begin{tabular}{lccc}
\hline Taxon & Locality & 16S & CO1 \\
\hline Scylla serrata 1 & Pulicat & JX446640 & - \\
Scylla serrata 2 & Tuticorin & JX446641 & - \\
Scylla serrata 3 & Kakinada & JX446642 & - \\
Scylla serrata 6 & Kollam & KC154084 & - \\
Scylla serrata 7 & Cochin & KC154085 & - \\
Scylla serrata 8 & Vembanad & KC154086 & KC154081 \\
Scylla serrata 9 & Karwar & KC154087 & KC154082 \\
Scylla serrata 10 & Chilka & KC154088 & KC154083 \\
Scylla olivacea 1 & Porto Nova & JX446635 & - \\
Scylla olivacea 2 & Kovalam & JX446636 & - \\
Scylla olivacea 3 & Kakinada & JX446638 & - \\
Scylla olivacea 4 & Kakinada & JX446638 & - \\
Scylla olivacea 5 & Goa & JX446639 & - \\
Scylla olivacea 6 & Cochin & KC154070 & KC154075 \\
Scylla olivacea 7 & Mangalore & KC154071 & KC154069 \\
Scylla olivacea 8 & Karwar & KC154072 & KC154076 \\
Scylla olivacea 9 & Karwar & KC154073 & KC154077 \\
Scylla olivacea 10 & Cochin & KC154074 & KC154078 \\
Scylla tranquebarica & Pulicat & JX446643 & KC154079 \\
morphotype 1 & & & \\
Scylla tranquebarica & Tranquebar & JX446644 & KC154080 \\
morphotype 2 & & & \\
\hline
\end{tabular}

Table 2. GenBank sequences used in analyses.

\begin{tabular}{lccc}
\hline Species & $\begin{array}{c}\text { Gene } \\
\text { region }\end{array}$ & $\begin{array}{c}\text { Locality in } \\
\text { GenBank }\end{array}$ & Accession \\
\hline Scylla serrata & $16 \mathrm{~S}$ & Taiwan & AF109318 \\
S. olivacea & $16 \mathrm{~S}$ & Taiwan & AF109321 \\
S. tranquebarica & $16 \mathrm{~S}$ & Taiwan & AF109320 \\
S. paramamosain & $16 \mathrm{~S}$ & Taiwan & AF109319 \\
S. tranquebarica & $16 \mathrm{~S}$ & India & KF220544 \\
S. tranquebarica & $16 \mathrm{~S}$ & India & KF220543 \\
S. tranquebarica & $16 \mathrm{~S}$ & India & KF220541 \\
S. tranquebarica & $16 \mathrm{~S}$ & India & KF220539 \\
S. tranquebarica & $16 \mathrm{~S}$ & India & KF220538 \\
S. tranquebarica & $16 \mathrm{~S}$ & India & KF220537 \\
S. serrata & $\mathrm{CO} 1$ & Red sea & AF097011 \\
S. serrata & $\mathrm{CO} 1$ & Australia & AF097002 \\
S. olivacea & $\mathrm{CO} 1$ & Australia & AY373355 \\
S. tranquebarica & $\mathrm{CO} 1$ & Australia & AY373353 \\
S. paramamosain & $\mathrm{CO} 1$ & China & AY750930 \\
Outgroup & & & \\
\multicolumn{1}{c}{ Portunus pelagicus } & $16 \mathrm{~S}$ & Australia & FJ812329 \\
P. pelagicus & $\mathrm{CO} 1$ & China & AF082732 \\
\hline
\end{tabular}

Table 3. Summary of sequence characteristics of two mitochondrial gene regions.

\begin{tabular}{lcc}
\hline Gene region & $16 \mathrm{~S}$ & $\mathrm{CO} 1$ \\
\hline Number of samples & 30 & 10 \\
Alignment length & 592 & 549 \\
Base frequency & & \\
$\mathrm{A}$ & 34.8 & 26.7 \\
$\mathrm{C}$ & 12.0 & 18.6 \\
$\mathrm{G}$ & 19.2 & 16.6 \\
$\mathrm{~T}$ & 34.0 & 38 \\
Transition/transversion & 1.83 & 2.2 \\
No of variable sites & 107 & 122 \\
Parsimony informative sites & 81 & 85 \\
Gamma distribution & 0.3466 & 0.4471 \\
\hline
\end{tabular}

two mitochondrial regions produces trees with similar topology, showing two distinct congeneric clusters supported by high bootstrap value indicating high percentage support for grouping (Figures 2 and 3). In 16 S tree all S. serrata and S. tranquebarica morphotype sequences obtained during this study reciprocally monophyletic with $16 \mathrm{~S}$ reference sequence of $S$. serrata (Figure 2). Further, six S. tranquebarica sequences from India retrieved from Genbank also clustered with $S$. serrata reference sequence. Sequences of $S$. olivacea obtained during this study formed a single cluster grouped with reference $S$. olivacea. Phylogenetic relationship inferred from $\mathrm{CO} 1$ sequence data was consistent with those inferred by $16 \mathrm{~S}$ sequence and showed no difference between $S$. serrata and $S$. tranquebarica morphotypes identified in this study (Figure 3). The average genetic distance between and within species was calculated based on Kimura 2-parameter model. The average distance within $S$. serrata and S. olivacea were $0.008639 \pm 0.001058$ and $0.006837 \pm 0.001681$, respectively. However, the distance between these two species was more than 10 times (Table 4).

\section{Discussion}

The present study demonstrated that mud crabs of India are composed of two species: S. serrata and S. olivacea, which have long been misidentified as $S$. tranquebarica and $S$. serrata respectively. Further, species identified as $S$. tranquebarica morphotypes in this study and the sequences deposited previously in the GenBank as S. tranquebarica from Indian waters were reciprocally monophyletic with $S$. serrata clad. The discrimination of $S$. serrata and $S$. tranquebarica has often been problematic owing to the overlapping and subtle morphological diagnostic characters (e.g. relative size of frontal teeth and spines on the outer carpus and variation in the polygonal marking on the cheliped and pereopods). Keenan et al. (1998) identified these species using molecular and morphometric tools. Jirapunpipat et al. (2008), however, were unable to identify Thai population of $S$. serrata and $S$. tranquebarica using almost similar morphometric characters used by Keenan et al. (1998). They found overlap of $S$. serrata and $S$. tranquebarica although these two species are clearly distinguishable from $S$. olivacea and $S$. paramamosain using discriminant function analysis. Further, none of the thirtyone $16 \mathrm{~S}$ sequences analyzed from Thailand matches with reference sequence of $S$. tranquebarica (Somboonna et al., 2010). Regional taxonomic studies carried out in Vietnam (Macintosh et al., 2002), China (Ma et al., 2006, 2012) and South Africa (Davis, 2004), also indicate the absence of $S$. tranquebarica in these regions. Recently, Mandal et al. (2013) also reported the absence of $S$. tranquebarica from Indian waters. The morphotypes assigned for $S$. tranquebarica in this study could be a phenotype extreme of $S$. serrata.

The taxonomy of mud crabs in India was studied by Joel \& Raj (1983) and Kathirval \& Srinivasagam (1992), and they demonstrated $S$. tranquebarica as a synonym of $S$. oceanica, which is currently synonymized as $S$. serrata by Keenan et al. (1998). Majority of the scientific literature published from India under the name $S$. tranquebarica should be $S$. serrata, and therefore, caution should be taken while interpreting the previously published biological and aquaculture data from Indian sub continent.

As $S$. tranquebarica was originally described from India (type locality: South India; Keenan et al., 1998), it is unlikely to exclude the possibility of existence of $S$. tranquebarica in Indian waters, although none of the sequences obtained during our study matches with reference sequence of $S$. tranquebarica. Further, Keenan et al. (1998) also opined the possibility of existence of this species in the Indian sub continent. The absence of $S$. tranquebarica in the present study could be due to the far less 


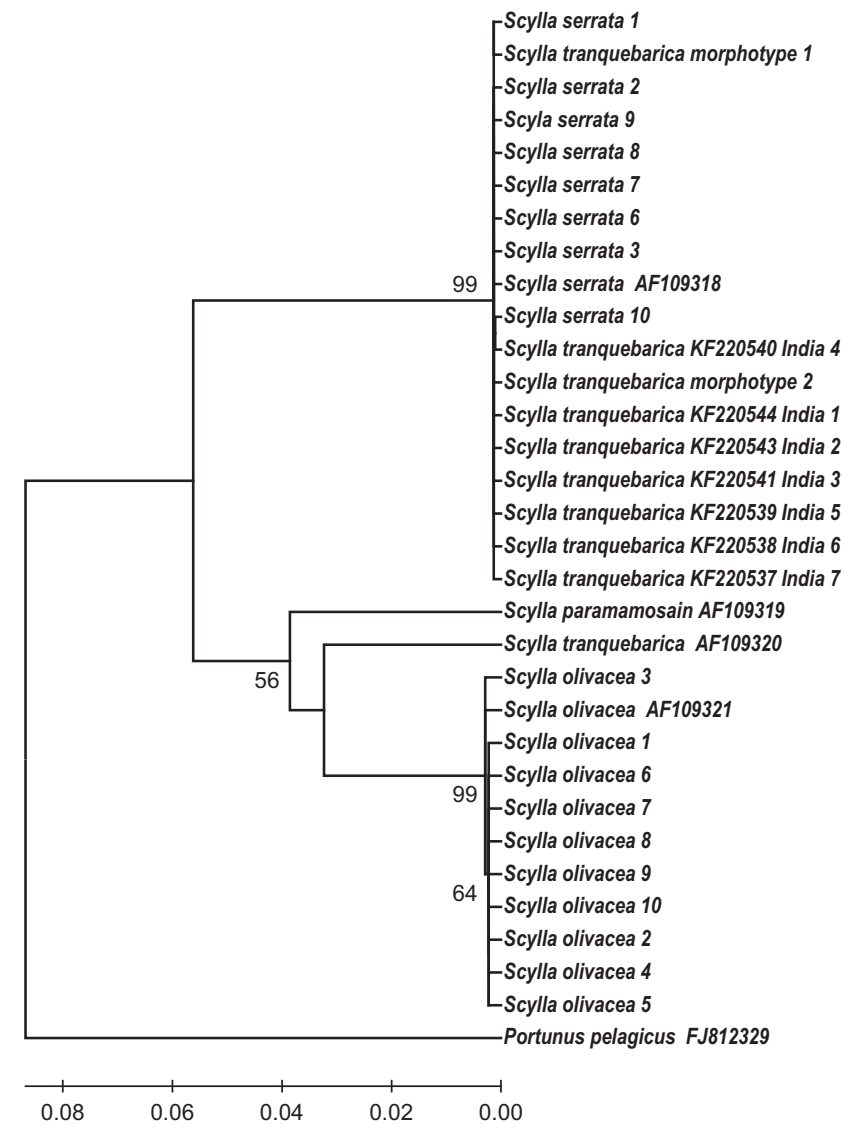

Figure 2. Neighbor Joining (NJ) phylogenetic tree of Indian mud crabs based on the Kimura 2-parameter genetic distance inferred from DNA sequences of mitochondrial gene $16 \mathrm{~S}$ rRNA. Bootstrap values based on 1000 replications are indicated at the nodes. Only bootstrap values $>50 \%$ are shown. Refer Table 2 for species designation.

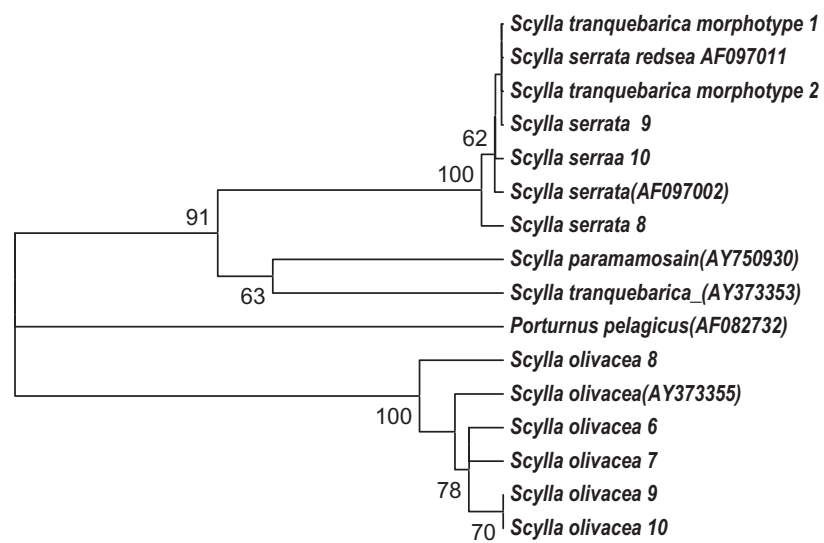

\begin{tabular}{cccc}
\hline & 1 & 1 & \\
\hline 0.06 & 0.04 & 0.02 & 0.00
\end{tabular}

Figure 3. Neighbor Joining (NJ) phylogenetic tree of Indian mud crabs based on the Kimura 2-parameter genetic distance inferred from DNA sequences of mitochondrial gene COI. Bootstrap values based on 1000 replications are indicated at the nodes. Only bootstrap values $>50 \%$ are shown. Refer Table 2 for species designation.

abundance of this species in Indian waters. Further, this species are found to be relatively less abundant even in its distributional range (Jirapunpipat et al., 2009).

As morphological variations used to discriminate $S$. tranquebarica and $S$. serrata are subtle, it is often difficult to apply morphological data alone with rigor, particularly during the field
Table 4. Summary of pair wise distance of $16 \mathrm{~S}$ and CO1 showing the mean and standard error of $\mathrm{K} 2 \mathrm{P}$ distance in different groupings.

\begin{tabular}{lcc}
\hline & $16 \mathrm{~S}$ & CO1 \\
\hline Within S. serrata & $0.008639 \pm 0.001058$ & $0.003797 \pm 0.000824$ \\
Within S. olivacea & $0.006837 \pm 0.001681$ & $0.019387 \pm 0.002635$ \\
S. serrata Vs S. olivacea & $0.106485 \pm 0.004837$ & $0.180726 \pm 0.000718$ \\
\hline
\end{tabular}

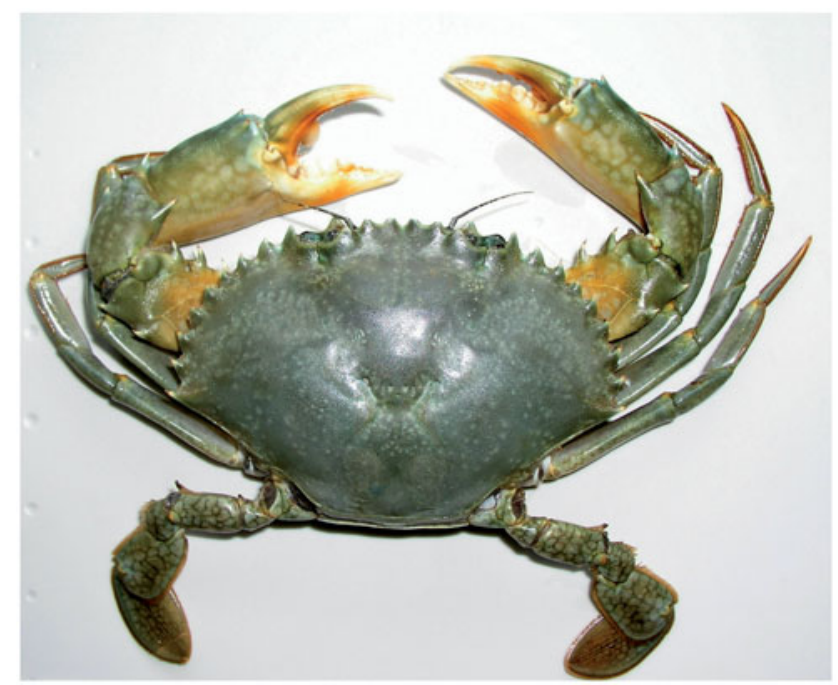

Figure 4. Photograph of Scylla serrata (Forskal, 1775), dorsal view of male (carapace width: $96.5 \mathrm{~mm}$ ).

identification (Jirapunpipat et al., 2009). During the present study, few specimens were identified as $S$. tranquebarica in the field, and subsequent molecular analysis proved them as $S$. serrata with $100 \%$ bootstrap support. Therefore, it is suggested that at least in some cases molecular analysis is needed to identify the specimens positively. $S$. serrata is the most preferred species for aquaculture in India (Kathirvel et al., 2004), and many tropical south-east Asian countries, and therefore, it is imperative to select founder population using molecular tools for commercial breeding program.

Although close morphological similarity of $S$. tranquebarica and $S$. serrata have been reported by many workers (Ikhwanuddin et al., 2011; Jirapunpipat et al., 2009), genetic analysis shows that $S$. tranquebarica and $S$. olivacea are more closely related than $S$. serrata (Figure 3). This might indicate that $S$. tranquebarica and $S$. olivacea are the result of very recent speciation. Other studies also found close genetic similarity of $S$. tranquebarica and S. olivacea (Fuseya \& Watanabe, 1996; Keenan, 1999; Ma et al., 2006). Keenan et al. (1998) delineated Scylla as four well supported species with average level of inter specific sequence difference $(\sim 12 \%)$ more than six times greater than that observed at the intra-specific level (2\%). A $3 \%$ divergence in the CO1 sequence has been accepted for distinguishing closely related animal species (Hebert et al., 2003). Thus, large genetic difference observed between $S$. serrata and $S$. olivacea in the present study confirm the distinct species level difference.

\section{Diagnosis of the common species of Scylla in the Indian waters}

\section{Scylla serrata Forskal}

Carapace colour predominantly greenish to greyish green (Figure 4). Carapace, legs and abdomen (females only) with polygonal patterning. Frontal lobe teeth sharp and equal in size. 


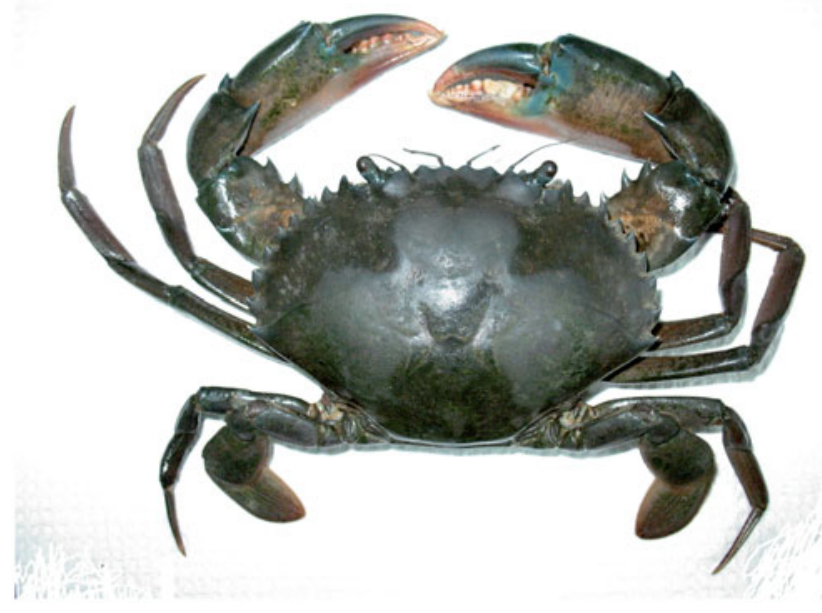

Figure 5. Photograph of Scylla olivacea (Herbst, 1796) dorsal view of male (carapace width: $82.9 \mathrm{~mm}$ )

Two sharp spines at the outer margin of the carpus of the cheliped. The ratio between frontal lobe width and Internal carapace width is $0.38 \pm 0.01$.

\section{Scylla olivacea Herbst}

Carapace colour predominantly red to brown (Figure 5). Carapace rounded with blunt, obtuse frontal teeth, all equal in size with shallow inter space. Short obtuse antero-lateral spines uniform in size and shape. Carpus of chelipeds usually with one obtuse small blunt prominence. Chelipeds legs and abdomen all without obvious polygonal patterning. The ratio between frontal lobe width and internal carapace width is $0.48 \pm 0.01$.

\section{Conclusion}

Identification of mud crabs of genus Scylla has been contentious for a long time. In the present paper, the comprehensive DNA sequence analysis of mud crabs of India revealed that species commonly reported as $S$. tranquebarica should be $S$. serrata. Further S. olivacea has often been misidentified as S. serrata in most scientific literature from India. The present work resolves the taxonomic ambiguity of mud crabs of India.

\section{Acknowledgements}

We are grateful to Dr M. Kathirvel for providing encouragement and assistance. We are especially grateful to $\mathrm{Mr} \mathrm{N}$. Dineshkumar for the assistance in construction of phylogenetic tree. We also extend our appreciation to $\mathrm{Dr}$ S. Kulasekarapandian for his encouragement and assistance during this work. We thank Mr D. M. Rameshbabu for the assistance in the collection of samples.

\section{Declaration of interest}

The authors report no conflicts of interest. The authors alone are responsible for the content and writing of the paper.

\section{References}

Davis JA. (2004). Development of hatchery technology for the mud crab Scylla serrata (Forskal) in South Africa. Doctoral Dissertation, University of Ghent, Belgium.

Estampador EP. (1949). Studies on Scylla (Crustacea: Portunidae): Revision of the genus. Phil J Sci 78:95-108.

Felsenstein J. (1993). PHYLIP (Phylogeny Inference Package) Version 3.50. Distributed by the author. Department of Genetics, University of Washington, Seattle, USA.
Fuseya R, Watanabe S. (1996). Genetic variability in the mud crab genus Scylla (Brachyura: Portunidae). Fish Sci 62:705-9.

-Hebert PDN, Cywinska A, Ball SL, deWaard JR. (2003). Biological identification through DNA barcodes. Pro R Soc B 270:313-32.

- Iamai H, Cheng J, Hamasaki K, Numachi K. (2004). Identification of four mud crab species (Genus Scylla) using ITS-1 and 16s rDNA markers. Aquat Living Resour 17:31-4.

-Ikhwanuddin M, Azmie G, Juariah HM, Zakaria MZ, Ambak MA (2011). Biological information and population features of mud crab, genus Scylla from mangrove areas of Sarawak, Malaysia. Fish Res 108: 299-306.

Jirapunpipat K, Aungtonya C, Watanabe S. (2008). Morphological study and application of multivariate analysis for the mud crab genus Scylla in Klongngao mangrove, Ranong province, Thailand. Phuket Mar Bioll Res Bull 69:7-24.

Jirapunpipat K, Yokota M, Watanabe S. (2009). The benefits of speciesbased management of sympatric mud crabs migrating to a common fishing ground. ICES J Mar Sci 66:470-7.

- Jithendran KP, Poornima M, Balasubramanian CP, Kulasekarapandian S. (2010). Disease of mud crabs (Scylla spp.): an overview. Indian J Fish 57:55-63.

Joel DR, Raj PJS. (1983). Taxonomic remarks on two species of the genus Scylla De Haan (Portunidae: Brachyura) from Pulicat Lake. Indian J Fish 30:13-26.

Kathirval M, Srinivasagam S. (1992). Taxonomy of the mud crab, Scylla serrata (Forskal), from India. The mud crab: Report of the seminar on the mud crab culture and trade, Surat Thani, Thailand. p 172-32.

Kathirvel M, Kulasekarapandian S, Balasubramanian CP. (2004). Mud crab culture in India. Bull Central Instit Brackishwater Aquacult 17: $7-60$.

Kathirvel M. (1981). Present status of taxonomy and biology of Scylla serrata (Forskal). Workshop on Crustacean Biochemistry and Physiology, CMFRI and University of Madras, Chennai. p 1-12.

Keenan CP. (1999). The fourth species of Scylla. Proceedings of an International Scientific Forum, Darwin, Australia, 21-24 April 1997. ACIAR proceedings No 78. $\mathrm{p}$ 48-58.

Keenan CP, Davie PJF, Mann DL. (1998). A revision of the genus Scylla de Haan, 1833 (Crustacea: Decapoda: Brachyura: Portunidae Raffles). Bull Zool 46:217-45.

Kimura MA. (1980). Simple method for estimating rate of base substitutions through comparative studies of nucleotide sequences. J Mol Evol 16:111-20.

Kocher TD, Thomas WK, Meyer A, Edwards SV, Paboo S, Villablanca FX, Wilson AC. (1989). Dynamics of mitochondrial DNA evolution in animals: Amplification and sequencing with conserved primers. Proc Natl Acad Sci USA 86:6196-200.

Ma H, Ma C, Ma L. (2012). Molecular identification of genus Scylla (Decapoda: Portunidae) based on DNA barcoding and polymerase chain reaction. Biochem Sys Ecol 41:41-67.

- Ma L, Shang FY, Ma CY, Qiao ZG. (2006). Scylla paramamosain (Estampador) the most common mud crab (Genus Scylla) in China: Evidence from mtDNA. Aquacult Res 37:1694-8.

Macintosh D, Overton JL, Thu HVT. (2002). Confirmation of two mud crab species (Genus Scylla) in the mangrove ecosystem of Mekong Delta, Vietnam. J Shellfish Res 21:259-65.

Mandal A, Varkey M, Sobha PS, Anjali KM, Thampi Sam Raj YC. (2013). Molecular genetic approaches to resolve taxonomic ambiguity of mud crab species (Genus Scylla) in Indian waters. International Seminar Workshop on Mud Crab Aquaculture and Fisheries Management, Rajiv Gandhi Centre for Aquaculature and AQD SEAFDEC, New Delhi, 10-12 April, 2013, p 16.

Mohanty SK, Mohapatra A, Mohanty RK, Bhatta KS. (2006). Occurrence and biological outlines of two species of Scylla (De Haan) in Chilika lagoon, India. Indian J Fish 53:191-202.

Paterson BD, Mann DL. (2011). Mud crab aquaculture. In: Fotedar RK, Phillips BF, editors. Recent advances and new species in aquaculture. Oxford: Wiley-Blackwell. p 115-35.

Radhakrishnan CK, Samuel CT. (1982). Report on the occurrence of one sub species of Scylla serrata (Forskal) in Cochin back water. Fish Technol 19:5-7.

Ronquillo JD, Pura ZV, Trafalgar RM. (1999). Seedling production and pond culture of hatchery produced juveniles of the mud crab. Scylla oceanica Dana, 1852. Crustaceans and the Biodiversity crisis: Proceedings of fourth International Crustacean Congress, Amsterdam, The Netherlands, 20-24 April 1998. p 999-1012. 
- Somboonna N, Mangkalanan S, Udompetcharaporn A, Krittanai C, Sritunyalucksana K, Flegel TW. (2010). Mud crab susceptibility to disease from white spot syndrome virus is species-dependent. BMC Ress Notes 3:3-12.

-Stephenson W, Campbell B. (1960). The Australian Portunids (Crustacea: Portunidae) IV. Remaining genera. Australian J Mar Freshwater Res 11:73-122.

- Tamura K, Peterson D, Peterson N, Stecher G, Nei M, Kumar S. (2011). MEGA5: Molecular evolutionary genetics analysis using maximum likelihood, evolutionary distance, and maximum parsimony methods. Mol Biol Evol 28:2731-9.

Thompson JD, Higgins DG, Gibson TJ. (1994). CLUSTAL W: Improving the sensitivity of progressive multiple sequence alignment through sequence weighting, position-specific gap penalties and weight matrix choice. Nucleic acids Res 22:4673-80.

Wowor D, Ng PKL. (2007). The giant freshwater prawns of the Macrobrachium rosenbergii species group (Crustacea: Decapoda: Caridea: Palaemonidae). Raffles Bull Zool 55:321-36. 